\title{
From National Catholicism to Romantic Love: The Politics of Love and Divorce in Franco's Spain - ADDENDUM
}

\author{
Mónica García-Fernández \\ Contemporary History, University of the Basque Country, Faculty of Social Sciences and Communication, Leioa, Spain
}

doi:10.1017/S0960777321000515, Published online by Cambridge University Press: 10 November 2021

The original published version of this article did not include an abstract. The abstract has now been added and all versions updated.

\section{Reference}

García-Fernández, M. (2021). From National Catholicism to Romantic Love: The Politics of Love and Divorce in Franco's Spain. Contemporary European History, 1-13.

Cite this article: García-Fernández M (2022). From National Catholicism to Romantic Love: The Politics of Love and Divorce in Franco's Spain - ADDENDUM. Contemporary European History 31, 170-170. https://doi.org/10.1017/ S0960777322000017

(c) The Author(s), 2022. Published by Cambridge University Press. This is an Open Access article, distributed under the terms of the Creative Commons Attribution licence (https://creativecommons.org/licenses/by/4.0/), which permits unrestricted re-use, distribution, and reproduction in any medium, provided the original work is properly cited. 